김윤희 ${ }^{1} \cdot$ 백유진 $^{2 \star} \cdot$ 이은영 ${ }^{2}$

${ }^{1}$ 국립 부경대학교 간호학과, 2한림대학교 의과대학 성심병원 가정의학교실
접수일 : 2015년 1월 23일

수정일 : 2015년 7월 1일

승인일 : 2015년 7월 3일

*교신저자 : 백유진

한림대학교 성심병원 가정의학과 경기도 안양시 동안구 평촌동 896 우 431-070

Tel: 031-380-1784

Fax: 031-380-1782

E-mail: paek@hallym.or.kr

\section{How to Choose the Medications for Treating Nicotine Dependence?}

\author{
Yun-Hee Kim ${ }^{1}$, Yu-Jin Paek ${ }^{2 *}$, Eun-Young Lee ${ }^{2}$ \\ ${ }^{I}$ Department of Nursing, Pukyong National University, Busan, ${ }^{2}$ Department of Family Medicine, Hallym \\ University Medical Center, Hallym University College of Medicine, Anyang, Korea
}

\begin{abstract}
Several drugs and medications are in some way related to or used in the treatment of smoking cessation. The first line therapies for the treatment of nicotine dependence are nicotine replacement therapy (NRT), bupropion or varenicline. Various types of NRT are available such as patches, gums or lozenges. Theses medications can help with the craving for tobacco and withdrawal symptoms. Bupropion and varenicline work in a different way than nicotine replacement therapy. Bupropion may be used to delay weight gain shortly after smoking cessation among those who are afraid of weight gain or for people with depressive mood. Varenicline is the most effective drug when used as a single therapy. It works in the brain to reduce the physical effects of nicotine, However, this may have several serious reactions such as mental change or cardiovascular side effects which need close monitoring. Combination therapy of these medications can be applied to smokers who have failed previous cessation attempts.
\end{abstract}

Key Words: Smoking cessation; Nicotine dependence; Nicotine replacement therapy; Bupropion; Varenicline

Copyright (c) 2015 by Journal of the Korean Society for Research on Nicotine and Tobacco.

\section{서 론}

2008년 소개된 미국의 금연진료지침에서는 "임상의사는 금연하고자 하는 모든 환자들에게 약물치료를 권장해야 한 다. 단, 근거가 부족하거나 의학적으로 적응이 되지 않는 경 우는 제외된다(임산부, 하루흡연 양이 적은 흡연자 및 청소 년 등).”라고 명시하고 있다. 이렇게 금연약물을 선택할 때 장기간의 금연 성공률을 올리기 위한 일차 약물로는 니코틴 대체요법(Nicotine Replacement Therapy, NRT), 부프로 피온(Bupropion SR), 바레니클린(Varenicline)이 있으며,
이중 국내에서 구입가능한 NRT는 의사 처방없이 약국에서 구입할 수 있다.(1) NRT에는 패치, 껌, 그리고 로젠쯔(일종 의 사탕류) 세 가지 제형이 있다. 단일약물이 실패 혹은 효과 적이지 않을 경우 이차 약제인 노르트립틸린 등을 사용해 볼 수 있으며, 이들 약물의 병합요법에 대한 고려도 필요하다. 상담과 약물치료는 개별적으로 효과적임은 물론, 병행되었 을 때 더 효과적이므로 임상의사는 금연을 하고자 하는 모든 이들에게 상담과 약물치료를 병행하도록 한다. 


\section{본 론}

\section{1. 금연약물의 효과}

약물치료 단독보다는 약물치료와 상담 혹은 금연상담전 화를 결합했을 때 금연성공률이 증가한다는 사실은 잘 알려 져 있다. 약물치료 단독에 비해 금연상담전화를 병합하면 금 연성공률은 1.3 배, 전문상담을 병합하면 1.4 배 정도 올라간 다. 이때 상담횟수와 금연성공률은 비례한다고 한다. 한편, 전문상담에 약물을 병합하면 1.7 배 정도 금연성공률이 상승 한다.(1) 따라서 상담단독 혹은 약물단독 요법이 주가 되는 치료세팅을 운영하고 있다면 두 치료법이 함께 적용될 수 있 도록 노력하여야 한다.

금연약물치료의 효과크기는 전문적 상담과 결합된 경우 1 년 금연성공율이 NRT는 약 $15 \%$, 부프로피온은 약 $17 \%$, 바 레니클린은 약 $24 \%$ 이다. 전문상담이 결합되지 않으면 약물 치료 효과는 급격히 감소하여 1 년 금연성공율이 각각 7,8 , $12 \%$ 로 알려져 있다.(2)

니코틴 대체제는 부프로피온과 금연효과에서 별 차이가 없으며, 바레니클린은 NRT에 비해 1.51 배, 부프로피온에 비해서는 1.56 배 더 효과적이다(표 1).(3)

하지만 니코틴 병용요법과 바레니클린 간에 효과는 차이 가 없다.(3) 니코틴 패치 단독보다는 금연효과가 우월한 니 코틴 제제 병용요법이나 바레니클린 $2 \mathrm{mg} /$ 하루 용법을 적 극적으로 고려해 본다(표 2).

\section{1) 니코틴 대체요법}

흡연자는 정도의 차이는 있지만 담배를 피우지 않으면 니 코틴 부족으로 인한 금단증상(불안, 긴장, 불면증, 감각이상, 집중장애 등)이 생긴다. 니코틴 대체요법은 담배에서 발생 하는 발암물질이나 다른 독성물질에 노출됨이 없이 금연할

Table 1. Meta-analysis (2014): effects of smoking cessation medications.

\begin{tabular}{lc}
\hline \multicolumn{1}{c}{ Medications } & Estimated Odds Ratio (95\% confidence interval) \\
\hline Placebo & 1.0 \\
Varenicline (2 mg/day) & $2.88(2.4-3.5)$ \\
Nicotine Replacement Therapy & $1.84(1.7-2.0)$ \\
Gum (6-14 week) & $1.68(1.5-1.9)$ \\
Patch (6-14 week) & $1.91(1.7-2.2)$ \\
Bupropion SR & $1.62(1.5-1.8)$ \\
Nortriptyline & $2.01(1.5-2.8)$ \\
\hline
\end{tabular}

때의 금단증상을 줄이고 흡연욕구를 이겨내어 금연성공률 을 높이려는 목적으로 사용한다. 이때 공급되는 니코틴의 혈 중농도는 흡연처럼 급격하게 상승하지 않는다. 니코틴 대체 요법은 위약에 비해 약 1.84 배 정도의 금연율 상승효과가 있 다.(3)

니코틴을 외부에서 공급하는 방법으로는 패치(patch), 껌 (gum), 빨아먹는 정제(tablet/lozenge) 등이 있다. 패치는 비교적 일정한 농도를 16-24시간 동안 공급하며, 반면에 껌 은 패치에 비해 농도증가 속도가 빠르고 작용시간이 짧아 약 제 사용량을 조절할 수 있다. 니코틴 껌은 $2 \mathrm{mg}$ 과 $4 \mathrm{mg}$ 이 있 는데, 하루 25 개비 미만에서는 $2 \mathrm{mg}$ 을, 25 개비 이상에서는 $4 \mathrm{mg}$ 을 사용한다. 껌은 너무 급하게 씹는 경우 니코틴 방출 량이 급격하게 증가하고, 이에 따라 구강 내 점막을 통한 흡 수가 증가한다. 또한 타액에 의해 삼켜지기도 쉽다. 삼켜진 타액은 위나 식도점막의 자극을 초래한다. 소화기계 점막을 통해 흡수된 니코틴은 간에서 대사되기 때문에 효과가 미미 하다. 따라서 "씹고 거치하는" 방법을 잘 준수하여야 한다. $4 \mathrm{mg}$ 사탕은 기상 후 30 분 이내에 흡연을 개시하는 중등도 이상 니코틴 의존에서 처방된다. 반면 $2 \mathrm{mg}$ 사탕은 모든 흡 연자에서 기본적으로 사용할 수 있다.(4)

$\mathrm{NRT}$ 제제는 활동성 소화성궤양환자, 급성 심근경색후 2 주 이내, 불안정성 협심증, 심한 부정맥환자, 최근의 뇌중풍 등은 금기이다.

니코틴 패치는 금연일에 시작하여 처음 4 주는 니코틴 함 량이 제일 높은 것, 그 다음 2주는 중간단계, 그 다음 2 주는 제일 낮은 단계를 쓰는 것이 원칙이다. 12 주까지 연장해서 사용해 볼 수 있다. 체중이 $45 \mathrm{~kg}$ 이하이면 중간 농도 $(14 \mathrm{mg}$ 짜리)의 패치를 6 주간 사용하고 $7 \mathrm{mg}$ 을 그 다음 2 주간 사용 하면 된다. 패치의 경우 밤새 부착하고 있을 경우 불면증과 생생한 꿈을 야기할 수 있다. 이 경우 취침 직전에 패치를 제 거할 수 있다. 불면증이 있는 경우 16 시간 작용제로 사용한

Table 2. Meta-analysis (2014): effects of smoking cessation combined medications.

\begin{tabular}{lc}
\hline \multicolumn{1}{c}{ Medications } & Estimated Odds Ratio $(95 \%$ confidence interval) \\
\hline Placebo & 1.0 \\
Patch + Gum & $2.73(2.12-3.74)$ \\
Patch+Bupropion SR & $1.19(0.94-1.51)$ \\
\hline
\end{tabular}

${ }^{*}$ Compared to Nicotine replacement therapy only. 
다. 24 시간 제형이나 16 시간 제형의 금연효과는 유사하다. 하지만 24시간형이 아침기상 직후 흡연갈망과 금단증상을 감소시키는 데는 더 우월하다고 한다.(5) 따라서 밤새 패치 를 부착하지 않았던 경우에는 혈중 니코틴 농도가 낮아져 있 으므로 아침에 패치를 붙인 후 적절한 혈중농도에 이를 때 까지 속효성 NRT를 공급해 준다. 임산부나 수유부, 청소년 에 대한 안전성은 검증되어 있지 않지만 일부 연구에서 큰 부작용은 없는 것으로 보고하였다. 임산부의 경우 신진대사 항진으로 인하여 니코틴 분해가 빨라져 일반적인 니코틴 대 체요법으로는 금연효과가 없는 것으로 알려져 있다.(6)

NRT의 장기적 사용이 더 나은 금연성공을 보장하는 지는 확실치 않다.(7) 따라서 장기적 사용여부는 금연시도자의 상황에 따라서 적용하여야 한다. 완전한 금연이 어려운 흡연 자를 대상으로 흡연 위해성 감소(harm reduction) 목적으로 흡연양을 줄이면서 부족한 부분을 니코틴 대체제로 보충하 는 방법도 있다.

\section{2) 부프로피온(Bupropion SR)}

국내시판중인 부프로피온 제제 SR (sustained - release) 형과 XL (extended - release) 형 두 가지 중 금연치료에 허 가를 받은 제형은 SR 제형이다. SR 형은 일반적인 서방형 제 제로 치료용량의 약물이 장시간에 걸쳐 서서히 방출되는 제 제이다. XL 형은 약물이 초회 방출 후에 일정시간 간격을 두 고 2회 또는 3회 방출되도록 만든 제제이다.

부프로피온은 도파민과 노르아드레날린성을 가진 항우 울제로 개발되었으나 금연에 효과가 있음이 밝혀져 있으며, 위약에 비해 교차비 1.62 정도의 금연효과가 있음이 알려져 있다.(8) 이 약제의 금연효과는 우울증과는 무관하다. 이 약 의 장점은 경구로 복용할 수 있다는 점과 금연 이후의 체중 증가를 지연하는데 도움이 된다는 점이다.(9) 1,000 명 중에 1 명꼴로 경련의 위험성이 있다. 기타 두통, 무기력, 어지럼, 불면, 구강건조, 메스꺼움 등의 부작용이 있을 수 있다.(10) 부프로피온을 처방할 때 금기는 경련질환의 과거력이나 현재력, 중추신경계 종양, 대식증이나 신경성 식욕부진증의 과거력이나 현재력, 알콜 혹은 벤조디아제핀계 신경안정제 를 갑작스럽게 중단한 경우, 모노아민 산화효소 억제제 (MAOI) 동시 투여 등이며, 18세 이하 청소년과 임산부에서 는 안전성과 효능이 입증되지 않았다. $(11,12)$

금연예정일 1주전부터 하루 한 알 $(150 \mathrm{mg})$ 을 3일간 오전
에 투여한 후 다음 날부터 $150 \mathrm{mg}$ 을 하루 두 번 투여한다(혹 은 6일 동안 하루 한번 복용 후 7일째부터 하루 두 번 복용). 약을 투여한 후 적어도 8시간이 지난 후에 다음 번 약을 투여 하여야 한다. 서방정(Sustained Release)이므로 분쇄하거 나 씹어서 복용하지 않도록 한다. 경련과는 용량의존적 관계 가 있으므로 정해진 용량을 초과하지 않도록 주의한다. 적어 도 7주-12주 이상 사용한다. 두 연구에서는 $150 \mathrm{mg}$ 을 사용 하여도 하루 $300 \mathrm{mg}$ 의 용량과 유사한 금연성공률을 보였으 며 부작용은 더 적었다. 따라서 부작용이 예상되는 경우 하 루 한 알 용법도 경우에 따라 선택할 수 있다. $(13,14)$

\section{3) 노르트립틸린(Nortriptyline)}

노르트립틸린의 금연효능은 교차비가 2.0으로 부프로피 온과 거의 대등하거나 우월하다고 보고되고 있다(교차비 1.3[0.9-1.8]).(8) 이 약의 금연효과도 역시 항우울효과와는 무관하다. 우울증 치료제로 노르트립틸린을 연구한 보고들 에서는 가장 흔한 부작용은 구강건조였다. 그 외에 과도한 졸림, 변비, 요저류, 심장부작용 등이 보고되었고 과량 복용 할 경우 치명적인 것으로 보고되었다. 따라서 금연보조약물 로 처방할 때는 환자에게 약물을 사용할 때 생길 수 있는 이 득과 위험에 대해서 동의를 구하여야 한다. 보통 부프로피온 이나 니코틴 대체요법이 안 듣거나 부작용이 많은 경우 각 사례별로 처방을 고려할 수 있다.

노르트립틸린은 금연 1주 전부터 하루 2회 10-25 mg 사 용한다. 단독 혹은 니코틴 패치와 같이 사용할 수 있다.(15) 금기는 삼환계 항우울제 과민증, 녹내장, 최근 심근경색증, $\mathrm{MAO}$ 억제제 동시 투여, 18 세 이하 등이다. 노르트립틸린을 신중하게 투여해야할 경우는 경련성 질환의 현재 또는 과거 력, 심혈관계질환 혹은 갑상선기능 항진증, 조울증, 정신분 열증, 안압 증가, 배뇨 곤란, 고령 환자이다.(8)

\section{4) 바레니클린(Varenicline)}

바레니클린은 2006년부터 FDA의 승인을 얻어 시판되기 시작한 경구용 금연전문 의약품으로 뇌의 니코틴 아세틸콜 린 수용체(nicotinic acetylcholine receptors [nAChRs]) 에 대한 부분적 항진 및 억제 효과를 통해 금단증상 및 흡연 갈망을 줄여준다. 현재까지는 단독요법 중 금연효과가 가장 우월한 것으로 보고되고 있다.

금연개시일을 정하고 예정일 1주전부터 $0.5 \mathrm{mg}$ 알약을 오 
전에 3일간 복용, 이후 4일간 $0.5 \mathrm{mg}$ 하루 두 번으로 용량조 정기를 거쳐 금연개시일부터 $1 \mathrm{mg}$ 알약을 하루 두 번 복용한 다. 최소 12 주간 복용하며, 24 주까지 연장할 수도 있다.(16) 흔한 이상반응으로는 메스꺼움, 수면장애, 변비, 고창 등 이며, 이상야릇한 꿈, 두통 등이 보고되었다.

구역감은 $30 \%$ 에서 호소할 만큼 흔하지만, 증상은 경미하 며, 식사 후에 충분한 양의 물과 함께 복용하면 수 일-수 주 내에 점차 사라지는 것으로 알려져 있다. 청량음료는 피하는 것이 좋다. 그리고 지방질이 많은 음식이나 튀김식품은 피하 는 것이 좋다. 구역감을 줄이기 위해 metoclopramide 등의 항구역제를 함께 사용하는 경우 약물상호작용에 따른 부작 용이 보고된 바 있으므로 삼가야 한다.

바레니클린은 시판 후 조사에서 기분과 행동의 변화, 자 살충동 유발 등의 심각한 부작용이 일부에서 관찰되었으므 로 정신분열병, 양극성 정동장애, 주요우울증 등의 정신과 적 병력이 있었던 경우 처방에 주의하라고 권고되었다. 하지 만 최근의 보고에서 바레니클린은 정신과적 질환을 가진 환 자에서 자살관념이나 우울증 발생 등의 부작용은 관찰되지 않았다.(17) 정신질환자에서 바레니클린의 금연효과에 대 해서는 아직 불분명하다. $(18,19)$ 추후 대규모 연구가 필요하 다. 하지만 이 약물의 신경정신학적 위험성에 대한 모니터는 면밀히 수행하는 것이 좋겠다.

한편 2011년 6월에 캐나다 의사협회지에 실린 메타분석 에서 바레니클린 투여와 심각한 심혈관 질환의 발생사이에 연관성을 제기하여 논란이 된 바 있다.(20) 하지만 바레니클 린 관련 임상연구 모두를 포함한 2012년 BMJ 의 메타분석 에서는 유의미한 결과가 도출되지 않았다. (21) 특히 심혈관 질환 위험성이 낮은 환자에서 바레니클린이 심장병 위험을 증가시킬 가능성은 희박하다. 하지만 바레니클린의 심혈관 안전성과 심혈관 질환의 발병가능성에 대해서는 지속적인 모니터링이 필요하다.(22) 유럽에서 심혈관질환 고위험군 을 대상으로 시행한 연구에서 바레니클린은 일반적 간호군 에 비해 심혈관질환 발생을 낮추었다.(23)

한편, 일부 소규모 연구에서 금연개시일 4주전에 미리 바 레니클린 복용개시한 경우, 표준치료(금연지정일 1주전 치 료개시)보다 금연성공률이 높았다.(24) 또한 단박에 금연하 기 어려운 흡연자들에서 미리 12 주 간 바레니클린을 복용토 록 하고 흡연량을 점차 줄여 12 주 째에 금연을 시도한 경우, 위약군에 비해 금연성공율이 높았다. (25) 향후 추시가 필요
하다.

\section{5) 각 약제들 간의 병용}

니코틴 대체제 끼리의 병용요법 외에 타 약제들 간의 병용 요법에 대한 연구가 아직 많지 않고, 1 차 약제들 간의 선택에 대한 잘 고안된 알고리듬은 없다. 금연의 의지는 있으나 니 코틴 의존도가 높아 여러 가지 방법으로 금연에 실패한 경우 병용요법을 시도해볼 수 있다. 니코틴 대체제에 부프로피온 이나 노르트립틸린을 추가하는 경우 금연효과가 증강되는 지는 확실하지 않다. 최근 바레니클린에 니코틴 대체제를 병 용하는 연구가 보고되고 있다. 그 중 한 연구에서 12 주간 병 용한 결과 6개월 금연성공률이 바레니클린 단독요법보다 우 세하였다.(26) 두 약제를 병합하면 구역, 두통 등의 부작용 사례는 증가하는 것으로 보고된 바 있다. (27) 바레니클린과 부프로피온의 병합은 바레니클린 단독요법보다 장기 금연 성공률을 높이지는 않았다. (28) 부작용으로 불안증과 우울 은 더 많았다. 하지만, 추시가 필요하다.

\section{2. 금연약물의 선택}

의사는 환자의 선호도와 금기사항 등을 종합적으로 고려 하여 적절한 금연약물을 선택하여야 한다. 니코틴 의존의 표 식(기상 후 첫 30 분 이내 흡연, 하루 10 개비 이상 흡연, 니코 틴 의존도가 중간 이상인 경우 혹은 과거 금연시도에서 금단 증상이 심해 실패한 경우)이 있다면 적극적으로 약물요법을 시도한다.

성공적 금연을 위한 약물치료를 권유하기 위해서는 금연 약물 종류에 대한 설명, 니코틴 의존도 평가, 본인의 선호도 파악하고, 전문상담의 중요성 강조 등이 필요하다. 또한 약 물이 흡연욕구나 금단증상을 줄여주지만 완전히 제거하는 것이 아님을 알려주어야 한다.

약물치료를 원치 않는 경우에는 인지행동 대처법, 교육자 료 제공, 금연상담전화 안내 등 다른 자원으로 관리한다.

NRT는 기본적으로 모든 대상자에게 적용이 가능하다. 흡연자들은 약국에서 처방전 없이 구입할 수 있으므로 접근 성에서 편리하다. 특히 경구용 약물의 부작용에 두려움이 있 는 경우 선택할 수 있다. 용법이나 용량도 개별화해서 적용 하기가 용이하다. 다만, 피부자극이나 가려움증, 수면장애 등의 부작용을 잘 모니터해야 하고, 충분한 양의 니코틴을 공급할 수 있도록 조정하는 것이 중요하다. 패치와 껌(혹은 
사탕)의 병합요법의 효과를 잘 설명하는 것이 필요하다. 청 소년이나 임산부에서도 면밀한 평가 후에 시도해 볼 수 있 다.

부프로피온은 동반 우울증이 있을 때나 초기 체중증가 억 제가 이슈가 될 때 선택할 수 있다. 2주치를 처방하고, 다음 방문 때 부작용을 평가한 후, 부작용이 없다면 지속적으로 사용한다. 금단증상이 지속되면 NRT 병합에 대해 고려해 본다.

바레니클린은 금연효과가 가장 좋다. 다만 약가가 가장 비싸다. 가장 흔한 부작용인 구역감에 대한 설명을 충분히 하고, 이상한 꿈에 대해서도 확인해 본다. 정신행동적 변화 를 모니터하고, 이상이 없다면 12주 지속적인 사용을 권고 한다. 12 주 치료 종료 후에도 흡연충동이나 금연자신감이 부족하다면 12 주 가량 투여 연장을 해 볼 수 있다.

청소년의 경우 현재 $\mathrm{FDA}$ 의 허가를 득한 금연약물은 없 다. NRT (껌과 패치)와 부프로피온은 청소년을 대상으로는 제한적으로 임상연구가 진행되었다. NRT는 위약과 금연성 공율 차이가 없었다. 하지만 일부 연구에서 하루 흡연량 감 소 등의 효과는 제한적이나마 관찰되었다. 청소년에서 NRT 사용을 반대하는 연구자들은, NRT가 청소년에서 두뇌의 니 코틴 중독을 부추길 잠재성이 있다는 우려를 나타낸다. 한 편, 부프로피온의 경우 24세 미만의 우울증 환자에서 사용 할 경우 자살과 관련된 생각과 행동이 증가하는 것으로 조사 되었다. 바레니클린은 청소년을 대상으로 현재 임상 시험이 전세계적으로 진행되고 있다.(29) 전반적으로 청소년에서 금연약물의 장기적 효과는 전망이 그리 밝지 않다.

\section{결 론}

금연의 1 차 약제로 바레니클린 혹은 니코틴 병합요법을 추천한다. 니코틴 병합요법은 지속형 니코틴 패치에 속효성 니코틴 껌, 혹은 로젠쯔를 권고한다. 니코틴 대체요법은 일 반적으로 2-3개월 사용하지만 재흡연 가능성이 높다면 더 장기간 사용할 수도 있다. 바레니클린은 단독으로 사용할 경 우 가장 효과적인 금연약물로 정신행동 부작용의 가능성에 주의하면서 사용할 수 있다. 심장질환의 발생 가능성에도 관 심을 두어야 한다. 부프로피온은 우울 혹은 금연 후 체중증 가에 관심이 많은 경우 일차 약제로 고려할 수 있다. 또한 기 존의 처방에도 불구하고 실패한 흡연자들에서는 이들 약제
들 간의 조합을 신중하게 적용해 볼 수 있다.

\section{요 약}

금연에는 몇 가지 약물이 사용된다. 니코틴 의존에 사용 하는 1 차 약제로는 니코틴 대체요법, 부프로피온, 바레니클 린이 있다. 패치, 껌, 사탕 등 여러 가지 타입의 니코틴 대체 요법이 가능하다. 대체요법은 흡연갈망과 금단증상을 줄이 는 데 효과적이다. 부프로피온과 바레니클린은 니코틴 대체 요법이 작용하는 방식과는 다르게 효과를 발휘한다. 항우울 제인 부프로피온은 금연초기 체중증가를 예방하는 효과가 있어 체중증가를 염려하거나 우울증상을 가진 흡연자의 금 연을 보조한다. 바레니클린은 단일제제로는 가장 금연효과 가 좋다. 이 약물은 니코틴의 신체적 효과를 줄여준다. 하지 만 정신행동변화나 심혈관질환 부작용 등이 보고된 바 있어 면밀한 감시가 필요하다. 이러한 약제들의 병용요법은 이전 의 금연시도에 실패한 흡연자들에게 개별적으로 적용해 볼 수 있다.

중심단어: 금연; 니코틴 의존; 니코틴 대체요법; 부프로피 온; 바레니클린

\section{References}

1. Fiore MC, Jaén CR, Baker TB, Bailey WC, Benowitz NL, Curry SJ, et al. Treating tobacco use and dependence: 2008 update U.S. Public Health Service Clinical Practice Guideline executive summary. Respir Care 2008; 53(9): 1217-22.

2. Ferguson J, Bauld L, Chesterman J, Judge K. The English smoking treatment services: one-year outcomes. Addiction. 2005; 100(Suppl 2): 59-69.

3. Cahill K, Stevens S, Perera R, Lancaster T. Pharmacological interventions for smoking cessation: an overview and network meta-analysis. Cochrane Database Syst Rev 2013; 5: CD009329.

4. Stead LF, Perera R, Bullen C, Mant D, Hartmann-Boyce J, Cahill K, et al. Nicotine replacement therapy for smoking cessation. Cochrane Database Syst Rev 2012; 11: CD000146.

5. Shiffman S, Elash CA, Paton SM, Gwaltney CJ, Paty JA, Clark DB, et al. Comparative efficacy of 24-hour and 16-hour transdermal nicotine patches for relief of morning craving. Addiction 2000; 95(8): 1185-95.

6. Sharon Phelan. Smoking Cessation in Pregnancy. Obstetrics and Gynecology Clinics of North America 2014; 41(2): 255-66.

7. Schnoll RA, Patterson F, Wileyto EP, Heitjan DF, Shields AE, Asch DA, 
et al. Effectiveness of extended-duration transdermal nicotine therapy: a randomized trial. Ann Intern Med 2010; 152: 144-51.

8. Hughes JR, Stead LF, Hartmann-Boyce J, Cahill K, Lancaster T. Antidepressants for smoking cessation. Cochrane Database Syst Rev 2014; 1: CD000031.

9. Farley AC, Hajek P, Lycett D, Aveyard P. Interventions for preventing weight gain after smoking cessation. Cochrane Database Syst Rev 2012; 1: CD006219.

10. Aubin HJ. Tolerability and safety of sustained-release bupropion in the management of smoking cessation. Drugs 2002; 62(Suppl 2): 45-52.

11. Stanton A, Grimshaw G. Tobacco cessation interventions for young people. Cochrane Database Syst Rev 2013; 8: CD003289.

12. De Long NE, Barra NG, Hardy DB, Holloway AC. Is it safe to use smoking cessation therapeutics during pregnancy? Expert Opin Drug Saf 2014; 13(12): 1721-31.

13. Swan GE, McAfee T, Curry SJ, Jack LM, Javitz H, Dacey S, et al. Effectiveness of bupropion sustained release for smoking cessation in a health care setting: a randomized trial. Arch Intern Med 2003; 163: 2337-44.

14. Hays JT, Hurt RD, Rigotti NA, Niaura R, Gonzales D, Durcan MJ, et al. Sustained-release bupropion for pharmacologic relapse prevention after smoking cessation. a randomized, controlled trial. Ann Intern Med 2001; 135: 423-33.

15. Prochazka AV, Kick S, Steinbrunn C, Miyoshi T, Fryer GE. A randomized trial of nortriptyline combined with transdermal nicotine for smoking cessation. Arch Intern Med 2004; 164(20): 2229-33.

16. Tonstad S, Tønnesen P, Hajek P, Williams KE, Billing CB, Reeves KR, et al. Effect of maintenance therapy with varenicline on smoking cessation: a randomized controlled trial. JAMA 2006; 296: 64-71.

17. Thomas KH, Martin RM, Knipe DW, Higgins JP, Gunnell D. Risk of neuropsychiatric adverse events associated with varenicline: systematic review and meta-analysis. BMJ 2015; 350: h1109.

18. Kaduri P, Voci S, Zawertailo L, Chaiton M, McKenzie K, Selby P. Real-world effectiveness of varenicline versus nicotine replacement therapy in patients with and without psychiatric disorders. Addict Med 2015; 9(3): 169-76.
19. Kishi T, Iwata N. Varenicline for smoking cessation in people with schizophrenia: systematic review and meta-analysis. Eur Arch Psychiatry Clin Neurosci 2015; 265(3): 259-68.

20. Singh S, Loke YK, Spangler JG, Furberg CD. Risk of serious adverse cardiovascular events associated with varenicline: a systematic review and meta-analysis. CMAJ 2011; 183(12): 1359-66.

21. Prochaska JJ, Hilton JF. Risk of cardiovascular serious adverse events associated with varenicline use for tobacco cessation: systematic review and meta-analysis. BMJ 2012; 344: e2856.

22. Haber SL, Boomershine V, Raney E. Safety of varenicline in patients with cardiovascular disease. J Pharm Pract 2014; 27(1): 65-70.

23. Jennings C, Kotseva K, De Bacquer D, Hoes A, de Velasco J, Brusaferro $S$, et al. EUROACTION PLUS Study Group. Effectiveness of a preventive cardiology programme for high CVD risk persistent smokers: the EUROACTION PLUS varenicline trial. Eur Heart J 2014; 35(21): 1411-20.

24. Hajek P, McRobbie HJ, Myers KE, Stapleton J, Dhanji AR. Use of varenicline for 4 weeks before quitting smoking: decrease in ad lib smoking and increase in smoking cessation rates. Arch Intern Med 2011; 171: 770-7.

25. Ebbert JO, Hughes JR, West RJ, Rennard SI, Russ C, McRae TD, et al. Effect of varenicline on smoking cessation through smoking reduction: a randomized clinical trial. JAMA 2015; 313(7): 687-94.

26. Koegelenberg CF, Noor F, Bateman ED, van Zyl-Smit RN, Bruning A, O'Brien JA, et al. Efficacy of varenicline combined with nicotine replacement therapy vs varenicline alone for smoking cessation: a randomized clinical trial. JAMA 2014; 312: 155-61.

27. Ebbert JO, Burke MV, Hays JT, Hurt RD. Combination treatment with varenicline and nicotine replacement therapy. Nicotine Tob Res 2009; 11: $572-6$

28. Ebbert JO, Hatsukami DK, Croghan IT, Schroeder DR, Allen SS, Hays JT, et al. Combination varenicline and bupropion SR for tobaccodependence treatment in cigarette smokers: a randomized trial. JAMA 2014; 311: 155-63

29. Karpinski JP, Timpe EM, Lubsch L. Smoking cessation treatment for adolescents. J Pediatr Pharmacol Ther 2010; 15(4): 249-63. 